Research Article

\title{
Comparative Clinical Study of 'Panchavalkal Ointment' \& Framycetin Sulfate Cream (Local Application) in the Management of Infected Wound wrt Dushta Vrana
}

\author{
Anjna M Kulkarni', Amarprakash Dwivedi
}

${ }^{1}$ Ph.D. (Scholar), ${ }^{2}$ Professor, Shalya Tantra, School of Ayurveda, D.Y. Patil University, Navi Mumbai, Maharashtra, India. DOI: https://doi.org/10.24321/2394.6547.201910

\section{I $\quad \mathbf{N} \quad \mathbf{F} \quad \mathbf{O}$}

\section{Corresponding Author:}

Anjna M Kulkarni, Shalya Tantra, School of Ayurveda, D.Y. Patil University, Navi Mumbai, Maharashtra, India.

E-mail Id:

amk0709@gmail.com

Orcid Id:

https://orcid.org/0000-0002-7986-0382

How to cite this article:

Kulkarni AM, Dwivedi A. Comparative Clinical Study of 'Panchavalkal Ointment' \& Framycetin Sulfate Cream (Local Application) in the Management of Infected Wound wrt Dushta Vrana. J Adv Res Ayur Yoga Unani Sidd Homeo 2019; 6(3\&4): 17-24.

Date of Submission: 2020-02-20

Date of Acceptance: 2019-03-06

\section{$\begin{array}{llllllll}\mathbf{A} & \mathbf{B} & \mathbf{S} & \mathbf{T} & \mathbf{R} & \mathbf{A} & \mathbf{C} & \mathbf{T}\end{array}$}

A wound infection is major cause of delayed wound healing. Although there is a huge range of wound care available from Western medicine, their own side effects and increased resistance towards micro-organism leave a substantial space for herbal productwhich can cope-up with the sign and symptom of wound infection as well as accelerate the wound healing.

In this clinical study, Group A_Panchavalkal ointment was compared with Group B_Framycetin Sulfate cream, topically, in management of Dushta Vrana (infected wound). Assessment of pain was done by numerical rating scale. However, assessment of objective parameter such as size, depth, edges, undermining, necrotic tissue type, necrotic tissue amount, exudate type, exudate amount, skin color surrounding wound, peripheral tissue edema, peripheral tissue induration, granulation tissue, epithelialization evaluated by Bates-Jensen Wound Assessment Tool.

The wound status continuum between the two groups after treatment was compared. In Group A, 30.0\% woundachieved tissue health, 36.7\% healed, 26.7 regenerated and 6.7\% improved. In Group B only $13.3 \%$ woundachieved tissue health, $30.0 \%$ healed, $43.3 \%$ regenerated and $13.3 \%$ improved. The clinical analysis of objective parameters showed that both the medicines are effective to control wound infection, but it was observed that control in sign and symptom of wound infection was rapid in Group A and led to wound healing with less time duration in comparison to Group B.

The wound assessment revealed that both the groups were markedly efficacious in treating infected wound; moreover, the outcome was comparatively better in Group A. Hence, it is proved that Panchvalkal ointment was more effective than Framycetin Sulfate Cream in the management of infected wound w.s.r. to Dushta Vrana.

Keywords: Infected Wound, Framycetin Sulfate, Dushta Vrana, Panchvalkal 


\section{Introduction}

Infected wound remains a huge public health issue, at least in terms of morbidity and long term disability, throughout the world, especially in the developing countries. Almost $1 \%$ to $-1.5 \%$ of the population has a problem of wound at any one time. ${ }^{1,2}$

For the management of wound infection and delayed healing, anti-microbial and antiseptics are used topically.,4 However, due to development of resistance, limited role in wound healing and contraindication for prolonged use leaves a substantial space for herbal product which can cope-up with the sign and symptom of wound infection as well as accelerate the wound healing.

Description about the Vrana from its pre-stage (Vrana Shotha) to the holistic management (Shashthi-upakrama) is elaborately mentioned in Sushruta Samhita. Dushta Vrana, occurs either due to the vitiation of Doshas or improper treatment of Agantuja Vrana. ${ }^{5,6}$

Panchavalkal (barks of five trees) is having Vrana Shothahar (anti inflammatory), Vrana Shodhan (cleansing effect), Vrana Ropan (healing effect) and Varnya (improve skin texture) properties. Further, the phyto-chemical constituents (like tannins, flavanoids, phytosterols, glycosides, etc.) of Panchvalakal possess anti-microbial, anti-inflammatory activity, analgesic and wound healing activity. ${ }^{7,8,9}$

After keeping all the above facts in view, the proposed study was primarily aimed to compare a herbal product Panchavalkal ointment with standard drug from Western medicine Framycetin Sulfate Cream, topically in management of Dushta vrana (infected wound).

\section{Methodology}

Study Design: Randomized comparative clinical study.

Sample Size: 60 (divided in two groups, 30 patients for each group).

\section{Source of Data}

Drug Source: Raw material: Panchavalkal, i.e., bark of five trees (Nyegrodha - Ficus Benghalensis, Udumbar Ficus Glomerata, Ashwattha Ficus Religiosa, Parisha Thevetia Populnea \& Plaksha-Ficus Lacor), Tila tail \& Bees wax Preparation of medicine-in Ras shastra Department.

Sample Source: Patients suffering from Dushta Vrana have been selected from O.P.D and I.P.D. of D.Y. Patil Ayurvedic Hospital, Navi Mumbai, Maharashtra, India.

\section{Authentication \& Standardization}

The Institutional Ethical Committee Reference number for the proposed study is DYPUSA/17/513. Authentication of drug was carried out using microscopy technique and phytochemical test. Similarly, standardization of ointment is done by High Performance Thin Layer Chromatography and anti-microbial activity test by Minimum Inhibitory Concentration Test.

\section{Method of Collection of Data}

Patients with signs and symptoms of Dushta vrana (infected wound), Agantuj (acute) in nature were selected and enrolled with consent, for the research work.

\section{Inclusive Criteria}

- Above 16 to 60 years old, both gender

- Acute wound (Agantuj vrana)-surgical and traumatic with localized infection

- Wound healing by secondary intention

\section{Exclusive Criteria}

- Systemic disease Daibetes, Tuberculosis, Malignancy, HIV, Hepatitis B positive patient

- Venous, arterial, pressure ulcer and burns

- Deep tissue involvement like muscle, bone, tendon, viscera

- Systemic infection or spreading infection

- Suspicious or confirmed osteomyelitis

- Animal bites, macerated wound, thermal/ chemical or gun shot etc., injuries

\section{Investigation}

CBC, ESR, Blood sugar,, HIV- I\&II, HBsAg, X-ray of affected site (Desirable)

\section{Procedure of Dressing}

Wound cleaning was done with normal saline. In Group A, dressing was done with Panchavalkal ointment and in Group B with Framycetin Sulfate, using sterile gauze.

Duration: 21 days.

Dressing Change: Once in a day for one week, alternate day in next $2^{\text {nd }}$ and $3^{\text {rd }}$ week.

Observation: 28 days, assessment documented weekly.

\section{Assessment Criteria}

Subjective Parameter: Assessment of Pain by Numerical Rating Scale.

Objective parameter: Assessment by Bates-Jensen Wound Assesment Tool. ${ }^{10}$

\section{Observation and Result}

For this study, demographical data, i.e., age, gender, religion, socio-economic status, occupation, diet, Prakruti of the patients were the secondary aspects. They did not show much significance in drawing conclusion, as the assessment was based on clinical findings. 
Table I.Showing Gradation Parameters for Assessment of Result

\begin{tabular}{|c|c|c|}
\hline S. No. & Item & Assessment \\
\hline 1. & Size & $\begin{array}{c}\text { 0=Healed, resolved wound } \\
\text { 1=Length } x \text { width }<4 \mathrm{sq} \mathrm{cm} \\
\text { 2=Length } x \text { width } 4--<16 \mathrm{sq} \mathrm{cm} \\
3=\text { Length } x \text { width } 16.1--<36 \mathrm{sq} \mathrm{cm} \\
\text { 4=Length } x \text { width } 36.1--<80 \mathrm{sq} \mathrm{cm} \\
\text { 5=Length } x \text { width }>80 \mathrm{sq} \mathrm{cm}\end{array}$ \\
\hline 2. & Depth & $\begin{array}{l}\text { 0=Healed, resolved wound } \\
\text { 1=Non-blanchable erythema on intact skin } \\
\text { 2=Partial thickness skin loss involving epidermis \&/or dermis } \\
\text { 3=Full thickness skin loss involving damage or necrosis of subcutaneous } \\
\text { tissue; may extend down to but not through underlying fascia; \&/or mixed } \\
\text { partial \& full thickness \&/or tissue layers obscured by granulation tissue } \\
4=\text { Obscured by necrosis } \\
5=\text { Full thickness skin loss with extensive destruction, tissue necrosis or } \\
\text { damage to muscle, bone or supporting structures }\end{array}$ \\
\hline 3. & Edges & $\begin{array}{c}\text { 0=Healed, resolved wound } \\
\text { 1=Indistinct, diffuse, none clearly visible } \\
\text { 2=Distinct, outline clearly visible, attached, even with wound base } \\
3=\text { Well-defined, not attached to wound base } \\
\text { 4=Well-defined, not attached to base, rolled under, thickened } \\
5=\text { Well-defined, fibrotic, scarred or hyperkeratotic }\end{array}$ \\
\hline 4. & Under-mining & $\begin{array}{c}\text { 0=Healed, resolved wound } \\
1=\text { None present } \\
2=\text { Undermining }<2 \mathrm{~cm} \text { in any area } \\
\text { 3=Undermining } 2-4 \mathrm{~cm} \text { involving }<50 \% \text { wound margins } \\
4=\text { Undermining } 2-4 \mathrm{~cm} \text { involving }>50 \% \text { wound margins } \\
5=\text { Undermining }>4 \mathrm{~cm} \text { or Tunneling in any area }\end{array}$ \\
\hline 5. & $\begin{array}{c}\text { Necrotic Tissue } \\
\text { Type }\end{array}$ & 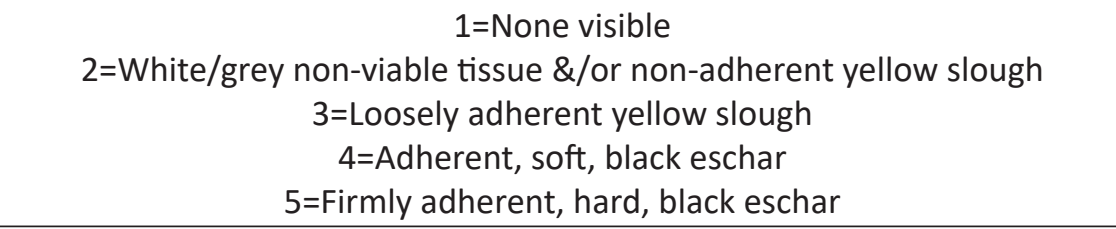 \\
\hline 6. & Necrotic Tissue Amount & $\begin{array}{c}1=\text { None visible } \\
2=<25 \% \text { of wound bed covered } \\
3=25 \% \text { to } 50 \% \text { of wound covered } \\
4=>50 \% \text { and }<75 \% \text { of wound covered } \\
5=75 \% \text { to } 100 \% \text { of wound covered }\end{array}$ \\
\hline 7. & Exudate Type & $\begin{array}{c}1=\text { None } \\
2=\text { Bloody } \\
\text { 3=Serosanguineous: thin, watery, pale red/pink } \\
4=\text { Serous: thin, watery, clear } \\
5=\text { Purulent: thin or thick, opaque, tan/yellow, with or without odor }\end{array}$ \\
\hline 8. & Exudate Amount & $\begin{array}{l}\text { 1=None, dry wound } \\
2=\text { Scant, wound moist but no observable exudate } \\
3=\text { Small } \\
4=\text { Moderate } \\
5=\text { Large }\end{array}$ \\
\hline
\end{tabular}




\begin{tabular}{|c|c|c|}
\hline 9. & $\begin{array}{c}\text { Skin Color } \\
\text { Sur-rounding Wound }\end{array}$ & $\begin{array}{c}\text { 1=Pink or normal for ethnic group } \\
\text { 2=Bright red \&/or blanches to touch } \\
\text { 3=White or grey pallor or hypopigmented } \\
\text { 4=Dark red or purple \&/or non-blanchable } \\
\text { 5=Black or hyperpigmented }\end{array}$ \\
\hline 10. & $\begin{array}{l}\text { Peripheral } \\
\text { Tissue Edema }\end{array}$ & $\begin{array}{c}\text { 1=No swelling or edema } \\
\text { 2=Non-pitting edema extends }<4 \mathrm{~cm} \text { around wound } \\
\text { 3=Non-pitting edema extends }>4 \mathrm{~cm} \text { around wound_ } \\
\text { 4=Pitting edema extends }<4 \mathrm{~cm} \text { around wound } \\
5=\text { Crepitus and/or pitting edema extends }>4 \mathrm{~cm} \text { around wound }\end{array}$ \\
\hline 11. & $\begin{array}{l}\text { Peripheral } \\
\text { Tissue Induration }\end{array}$ & $\begin{array}{c}\text { 1=None present } \\
\text { 2=Induration, }<2 \mathrm{~cm} \text { around wound } \\
3=\text { Induration } 2-4 \mathrm{~cm} \text { extending }<50 \% \text { around wound } \\
4=\text { Induration } 2-4 \mathrm{~cm} \text { extending }>50 \% \text { around wound } \\
5=\text { Induration }>4 \mathrm{~cm} \text { in any area around wound }\end{array}$ \\
\hline 12. & Granulation Tissue & $\begin{array}{c}\text { 1=Skin intact or partial thickness wound } \\
\text { 2=Bright, beefy red; } 75 \% \text { to } 100 \% \text { of wound filled } \& / \text { or tissue overgrowth } \\
\text { 3=Bright, beefy red; }<75 \% \&>25 \% \text { of wound filled } \\
\text { 4=Pink, \&/or dull, dusky red \&/or fills }<25 \% \text { of wound_ } \\
5=\text { No granulation tissue present }\end{array}$ \\
\hline 13. & Epithelialization & $\begin{array}{c}1=100 \% \text { wound covered, surface intact } \\
2=75 \% \text { to }<100 \% \text { wound covered } \& / \text { or epithelial tissue } \\
\text { extends }>0.5 \mathrm{~cm} \text { into wound bed } \\
3=50 \% \text { to }<75 \% \text { wound covered } \& / \text { or epithelial tissue extends to }<0.5 \mathrm{~cm} \text { into } \\
\text { wound bed } \\
4=25 \% \text { to }<50 \% \text { wound covered } \\
5=<25 \% \text { wound covered }\end{array}$ \\
\hline
\end{tabular}

\section{Assessment of Therapy on Subjective \& Objective Parameters}

Comparison of Effect of Therapy on Subjective \& Objective Parameters

Size: The mean size of group A wound before treatment $2.00 \pm 0.52$ was significantly reduced $(p<0.001)$ to $0.62 \pm 0.00$; similarly, it was reduced from $2.00 \pm 0.52$ to $0.70 \pm 0.70$ $(p<0.001)$ in group B subjects.

The \% of relief observed in Group A was $80 \%$ and in Group B was $65 \%$.

Depth: The mean depth of group A wound before treatment $2.76 \pm 0.92$ was significantly reduced $(p<0.001)$ to $0.40 \pm 0.56$; similarly, it was reduced from $2.76 \pm 0.40$ to $0.66 \pm 0.66$ $(p<0.001)$ in group B subjects.

The $\%$ of relief observed in Group A was $86.74 \%$ and in Group B was $75.90 \%$.

Edges: The mean edges score of group A wound before treatment $3.16 \pm 0.98$ was significantly reduced $(p<0.001)$ to $0.40 \pm 0.56$; similarly, it was reduced from $3.20 \pm 0.40$ to $0.70 \pm 0.74(p<0.001)$ in group $B$ subjects.

The \% of relief observed in Group A was $88.42 \%$ and in Group B was 78.12\%.
Undermining: The mean undermining score of group A wound before treatment $1.43 \pm 0.50$ was significantly reduced $(p<0.001)$ to $0.36 \pm 0.49$; similarly, it was reduced from $1.50 \pm 0.50$ to $0.53 \pm 0.50(p<0.001)$ in group $B$ subjects.

The \% of relief observed in Group A was $76.74 \%$ and in Group B was $66.44 \%$.

Necrotic Tissue Type: The mean necrotic tissue type of group A wound before treatment $2.73 \pm 0.52$ was significantly reduced $(p<0.001)$ to $0.70 \pm 0.46$; similarly, it was reduced from $2.76 \pm 0.50$ to $0.96 \pm 0.55(p<0.001)$ in group $B$ subjects.

The relief observed in Group A was $74.39 \%$ and in Group B was $65.06 \%$.

Necrotic Tissue Amount: The mean necrotic tissue amount of group $A$ wound before treatment $4.06 \pm 0.90$ was significantly reduced $(p<0.001)$ to $0.70 \pm 0.46$; similarly, it was reduced from $4.03 \pm 0.96$ to $0.93 \pm 0.44(p<0.001)$ in group $B$ subjects.

The \% of relief observed in Group A was $82.78 \%$ and in Group B was 76.85\%.

Exudate Type: The mean exudate type score of group $A$ wound before treatment $4.53 \pm 0.77$ was significantly reduced $(p<0.001)$ to $0.76 \pm 0.62$; similarly, it was reduced from $4.56 \pm 0.77$ to $1.00 \pm 0.64(p<0.001)$ in group $B$ subjects. 
The $\%$ of relief observed in Group A was $82.96 \%$ and in Group B was $77.77 \%$.

Exudate Amount: The mean exudate amount score of group A wound before treatment $3.66 \pm 0.60$ was significantly reduced ( $p<0.001$ ) to $0.76 \pm 0.56$; similarly, it was reduced from $3.70 \pm 0.59$ to $0.96 \pm 0.55(p<0.001)$ in group $B$ subjects.

The \% of relief observed in Group A was $79.09 \%$ and in Group B was 73.14\%.

Skin Colour Surrounding: The mean skin colour surrounding type of group A wound before treatment 3.03 \pm 1.09 was significantly reduced $(p<0.001)$ to $0.76 \pm 0.56$, similarly it was reduced from $2.96 \pm 1.12$ to $0.93 \pm 0.44(p<0.001)$ in group B subjects.

The \% of relief observed in Group A was $74.74 \%$ and in Group B was 68.53\%.

Peripheral Tissue Edema: The mean peripheral tissue edema of group A wound before treatment $1.93 \pm 0.25$ was significantly reduced $(p<0.001)$ to $0.70 \pm 0.46$; similarly, it was reduced from $1.93 \pm 0.25$ to $0.86 \pm 0.34(p<0.001)$ in group B subjects.

The \% of relief observed in Group A was $63.79 \%$ and in Group B was 55.17\%.

Peripheral Tissue Induration: The mean peripheral tissue induration score of group A wound before treatment $1.73 \pm 0.44$ was significantly reduced $(p<0.001)$ to $0.70 \pm 0.46$; similarly, it was reduced from $1.73 \pm 0.44$ to $0.86 \pm 0.34$ $(p<0.001)$ in group B subjects.

The \% of relief observed in Group A was $59.61 \%$ and in Group B was $50 \%$.

Granulation Tissue: The mean granulation tissue score of group A wound before treatment $3.90 \pm 0.95$ was significantly reduced $(p<0.001)$ to $0.76 \pm 0.56$; similarly, it was reduced from $3.86 \pm 0.93$ to $1.10 \pm 0.75(p<0.001)$ in group $B$ subjects.

The \% of relief observed in Group A was $80.34 \%$ and in Group B was $71.55 \%$.

Epithelisation: The mean epithelisation score of group A wound before treatment $4.93 \pm 0.25$ was significantly reduced $(p<0.001)$ to $1.10 \pm 0.40$; similarly, it was reduced from $4.93 \pm 0.25$ to $1.30 \pm 0.83(p<0.001)$ in group $B$ subjects.

The \% of relief observed in Group A was $77.70 \%$ and in Group B was 73.64\%.

Pain: The mean pain score of group A wound before treatment $5.96 \pm 1.27$ was significantly reduced $(p<0.001)$ to $0.26 \pm 0.58$; similarly, it was reduced from $6.00 \pm 1.11$ to $0.40 \pm 0.72(p<0.001)$ in group $B$ subjects.

The \% of relief observed in Group A was $95.50 \%$ and in Group B was 93.33.12\%.

Thus, by analyzing the data, it is observed that after the treatment, in Group A mean score value of all parameters was less than Group B, hence, the treatment of Group A (Panchvalkal ointment) had worked better than Group B (Framycetin Sulfate Cream).

Table 2.Showing Comparison of effect of therapy on Subjective \& Objective parameters

\begin{tabular}{|c|c|c|c|c|c|c|c|c|c|c|}
\hline Variable & Time & Groups & $n$ & Mean & S.D. & Median & Min. & Max & z-value & $p$-value ${ }^{*}$ \\
\hline \multirow{4}{*}{ SIZE } & \multirow{2}{*}{ BT } & Group A & 30 & 2.00 & 0.52 & 2.00 & 1.00 & 3.00 & 0.000 & 1.000 \\
\hline & & Group B & 30 & 2.00 & 0.52 & 2.00 & 1.00 & 3.00 & & \\
\hline & \multirow{2}{*}{ AT } & Group A & 30 & 0.43 & 0.62 & 0.00 & 0.00 & 2.00 & -1.572 & 0.116 \\
\hline & & Group B & 30 & 0.70 & 0.70 & 1.00 & 0.00 & 2.00 & & \\
\hline \multirow{4}{*}{ Depth } & \multirow{2}{*}{ BT } & Group A & 30 & 2.76 & 0.43 & 3.00 & 2.00 & 3.00 & 0.000 & 1.000 \\
\hline & & Group B & 30 & 2.76 & 0.43 & 3.00 & 2.00 & 3.00 & & \\
\hline & \multirow{2}{*}{ AT } & Group A & 30 & 0.40 & 0.56 & 0.00 & 0.00 & 2.00 & -1.636 & 0.102 \\
\hline & & Group B & 30 & 0.66 & 0.66 & 1.00 & 0.00 & 2.00 & & \\
\hline \multirow{4}{*}{ Edges } & \multirow{2}{*}{ BT } & Group A & 30 & 3.16 & 0.98 & 3.00 & 2.00 & 5.00 & -0.275 & 0.783 \\
\hline & & Group B & 30 & 3.20 & 0.92 & 3.00 & 2.00 & 5.00 & & \\
\hline & \multirow{2}{*}{ AT } & Group A & 30 & 0.40 & 0.56 & 0.00 & 0.00 & 2.00 & -1.644 & 0.100 \\
\hline & & Group B & 30 & 0.70 & 0.74 & 1.00 & 0.00 & 3.00 & & \\
\hline \multirow{4}{*}{ Undermining } & \multirow{2}{*}{ BT } & Group A & 30 & 1.43 & 0.50 & 1.00 & 1.00 & 2.00 & -0.513 & 0.608 \\
\hline & & Group B & 30 & 1.50 & 0.50 & 1.50 & 1.00 & 2.00 & & \\
\hline & \multirow{2}{*}{ AT } & Group A & 30 & 0.36 & 0.49 & 0.00 & 0.00 & 1.00 & -1.287 & 0.198 \\
\hline & & Group B & 30 & 0.53 & 0.50 & 1.00 & 0.00 & 1.00 & & \\
\hline
\end{tabular}




\begin{tabular}{|c|c|c|c|c|c|c|c|c|c|c|}
\hline \multirow{4}{*}{$\begin{array}{l}\text { Necrotic } \\
\text { Tissue } \\
\text { Type }\end{array}$} & \multirow{2}{*}{ BT } & Group A & 30 & 2.73 & 0.52 & 3.00 & 2.00 & 4.00 & -0.264 & 0.792 \\
\hline & & Group B & 30 & 2.76 & 0.50 & 3.00 & 2.00 & 4.00 & & \\
\hline & \multirow{2}{*}{ AT } & Group A & 30 & 0.70 & 0.46 & 1.00 & 0.00 & 1.00 & -1.883 & 0.060 \\
\hline & & Group B & 30 & 0.96 & 0.55 & 1.00 & 0.00 & 3.00 & & \\
\hline \multirow{4}{*}{$\begin{array}{l}\text { Necrotic } \\
\text { Tissue } \\
\text { Amount }\end{array}$} & \multirow{2}{*}{ BT } & Group A & 30 & 4.06 & 0.90 & 4.00 & 2.00 & 5.00 & -0.070 & 0.944 \\
\hline & & Group B & 30 & 4.03 & 0.96 & 4.00 & 2.00 & 5.00 & & \\
\hline & \multirow{2}{*}{ AT } & Group A & 30 & 0.70 & 0.46 & 1.00 & 0.00 & 1.00 & -1.883 & 0.060 \\
\hline & & Group B & 30 & 0.93 & 0.44 & 1.00 & 0.00 & 2.00 & & \\
\hline \multirow{4}{*}{$\begin{array}{l}\text { Exudate } \\
\text { Type }\end{array}$} & \multirow{2}{*}{ BT } & Group A & 30 & 4.53 & 0.77 & 5.00 & 3.00 & 6.00 & -0.041 & 0.967 \\
\hline & & Group B & 30 & 4.56 & 0.77 & 5.00 & 3.00 & 6.00 & & \\
\hline & \multirow{2}{*}{ AT } & Group A & 30 & 0.76 & 0.62 & 1.00 & 0.00 & 3.00 & -1.590 & 0.112 \\
\hline & & Group B & 30 & 1.00 & 0.64 & 1.00 & 0.00 & 3.00 & & \\
\hline \multirow{4}{*}{$\begin{array}{l}\text { Exudate } \\
\text { Amount }\end{array}$} & \multirow{2}{*}{ BT } & Group A & 30 & 3.66 & 0.60 & 4.00 & 3.00 & 5.00 & -0.235 & 0.814 \\
\hline & & Group B & 30 & 3.70 & 0.59 & 4.00 & 3.00 & 5.00 & & \\
\hline & \multirow{2}{*}{ AT } & Group A & 30 & 0.76 & 0.56 & 1.00 & 0.00 & 2.00 & -1.331 & 0.183 \\
\hline & & Group B & 30 & 0.96 & 0.55 & 1.00 & 0.00 & 3.00 & & \\
\hline \multirow{4}{*}{$\begin{array}{c}\text { Skin } \\
\text { Colour } \\
\text { Surrounding }\end{array}$} & \multirow{2}{*}{ BT } & Group A & 30 & 3.03 & 1.09 & 3.00 & 1.00 & 5.00 & -0.279 & 0.780 \\
\hline & & Group B & 30 & 2.96 & 1.12 & 3.00 & 1.00 & 5.00 & & \\
\hline & \multirow{2}{*}{ AT } & Group A & 30 & 0.76 & 0.56 & 1.00 & 0.00 & 2.00 & -1.313 & 0.189 \\
\hline & & Group B & 30 & 0.93 & 0.44 & 1.00 & 0.00 & 2.00 & & \\
\hline \multirow{4}{*}{$\begin{array}{l}\text { Peripheral } \\
\text { Tissue } \\
\text { Edema }\end{array}$} & \multirow{2}{*}{ BT } & Group A & 30 & 1.93 & 0.25 & 2.00 & 1.00 & 2.00 & 0.000 & 1.000 \\
\hline & & Group B & 30 & 1.93 & 0.25 & 2.00 & 1.00 & 2.00 & & \\
\hline & \multirow{2}{*}{ AT } & Group A & 30 & 0.70 & 0.46 & 1.00 & 0.00 & 1.00 & -1.554 & 0.120 \\
\hline & & Group B & 30 & 0.86 & 0.34 & 1.00 & 0.00 & 1.00 & & \\
\hline \multirow{4}{*}{$\begin{array}{l}\text { Peripheral } \\
\text { Tissue } \\
\text { Induration }\end{array}$} & \multirow{2}{*}{ BT } & Group A & 30 & 1.73 & 0.44 & 2.00 & 1.00 & 2.00 & 0.000 & 1.000 \\
\hline & & Group B & 30 & 1.73 & 0.44 & 2.00 & 1.00 & 2.00 & & \\
\hline & \multirow{2}{*}{ AT } & Group A & 30 & 0.70 & 0.46 & 1.00 & 0.00 & 1.00 & -1.554 & 0.120 \\
\hline & & Group B & 30 & 0.86 & 0.34 & 1.00 & 0.00 & 1.00 & & \\
\hline \multirow{4}{*}{$\begin{array}{l}\text { Granulation } \\
\text { Tissue }\end{array}$} & \multirow{2}{*}{ BT } & Group A & 30 & 3.90 & 0.95 & 4.00 & 2.00 & 5.00 & -0.134 & 0.894 \\
\hline & & Group B & 30 & 3.86 & 0.93 & 4.00 & 2.00 & 5.00 & & \\
\hline & \multirow{2}{*}{ AT } & Group A & 30 & 0.76 & 0.56 & 1.00 & 0.00 & 2.00 & -1.697 & 0.090 \\
\hline & & Group B & 30 & 1.10 & 0.75 & 1.00 & 0.00 & 3.00 & & \\
\hline & BT & Group A & 30 & 4.93 & 0.25 & 5.00 & 4.00 & 5.00 & 0.000 & 1.000 \\
\hline Enithelication & $\mathrm{D} 1$ & Group B & 30 & 4.93 & 0.25 & 5.00 & 4.00 & 5.00 & & \\
\hline eptrnemsation & $\Delta T$ & Group A & 30 & 1.10 & 0.40 & 1.00 & 1.00 & 3.00 & -0.909 & 0.363 \\
\hline & Al & Group B & 30 & 1.30 & 0.83 & 1.00 & 1.00 & 4.00 & & \\
\hline & BT & Group A & 30 & 5.96 & 1.27 & 6.00 & 4.00 & 8.00 & -0.107 & 0.915 \\
\hline Paiı & DI & Group B & 30 & 6.00 & 1.11 & 6.00 & 4.00 & 8.00 & & \\
\hline Palm & & Group A & 30 & 0.26 & 0.58 & 0.00 & 0.00 & 2.00 & -0.841 & 0.401 \\
\hline & Al & Group B & 30 & 0.40 & 0.72 & 0.00 & 0.00 & 3.00 & & \\
\hline
\end{tabular}


Antimicrobial Test: The Antimicrobial test was done by the agar cup diffusion method and minimum inhibitory concentration method for the estimation of the activity against microbial load, supported the clinical study, showing the result that it exhibited complete inhibition of microbial growth. Moreover, the antimicrobial test of Panchvalkal ointment done on four bacteria Staphylococcus aureus, Escherichia coli, Streptococcus pyogenes, Psedomonas and one fungi Candida albicans also shows zone of clearance against each microorganism and very much effective against S. aureus with MIC of $7.81 \mu \mathrm{g} / \mathrm{mL}$.

\section{The wound status continuum between the two groups after treatment}

Out of the 30 patients observed in Group A, 9 patients $(30.0 \%)$ achieved tissue health, 11 patients (36.7\%) healed, 8 patients $(26.7 \%)$ regenerated and 2 patients $(6.7 \%)$ improved with the dressing of Panchvalkal ointment.

Similarly, out of the 30 patients observed in Group B, 4 patients (13.3\%) achieved tissue health, 9 patients (30.0\%) healed, 13 patients (43.3\%) regenerated and 4 patients (13.3\%) improved with the dressing of Framycetin Sulfate cream.

Hence, from all above data, we can say that in terms of infection clearance as well as healing power, the Panchvalkal ointement is more effective than Framycetin Sulfate cream.

\section{Discussion}

In present study, 60 patients were selected with sign and symptom of localized wound infection (Dushta vrana) and divided in two groups: Group A was treated with Panchavalkal ointment and Group B was treated with Framycetin Sulfate Cream. Dressing was done for 21 days and weekly assessment till 28 days.

The clinical study showed that person with infected wound had moderated kind of pain which interfered significantly with regular activities and in both the groups pain reduced with reduction of wound infection. Patient of Group A were more comfortable at the time of dressing change and early reduction of Pain score was observed in Group A patient, which shows that dressing with Panchavalkal is more effective than Framycetin Sulfate in terms of pain reduction.

\section{Probable Mode of Action}

Ayurvedic Perspective: Panchavalkal is Kashaya ras, Sheeta Veerya, Varnya, Ruksha guna, Shotha hara, Sandhan kara, Pitta-Kapha har, Lekhan and Vrana ropan. ${ }^{11}$ According to Doshaghnata, Panchvalkal is having Kapha-Pitta hara property which may break the Samprapti (pathogenesis) of Dushta vrana. It must have helped reduce the sign of increased localized temperature and break the pain pathway which originates from inflammatory cells and occurs due to aggravated Pitta. The reduction of pus/ slough had occurred due to its Kapha har (anti Kapha) action. The Kashay ras (astringent property) helps reduce the amount of exudates; it acts as a Stambhaka (arresting) and Grahi (that holds). ${ }^{12}$ Due to all these properties, it must have reduced the Srava (discharge). The Stambhana effect might also be attributed to the Sheeta Veerya (cold in potency) of the drug.

Due to the Kashaya Rasa of the drug it acts with Ropana (healing) and Shodhana (cleansing effect) property, it destroys or liquefies the accumulated substances and, hence, minimizes the shoph/ induration. ${ }^{13}$ Furthermore, the drug is Rooksha (dryness) and Kaphahara. Moreover, the Lekhana (scraping), Kledahara (arresting Dampness), and Raktashodhaka (blood purifier) properties of Kashaya Rasa also facilitated the debridement of the slough. Similarly, by the property of Vrana ropan it might help accelerate the wound healing and with quality of Varnya it may help reduce the wound scar. Panchavalkala are considered to be Pittaghna, that is both by the action of Rasa (taste) and Veerya (potency) they are Pittahara and, therefore, they must decrease the Raga (redness)/ erythema.

Anti-Inflammatory Action: With the help of chemical constituents like tannins, flavanoids of Vata, Udumber and Ashwath, it is having pharmacological action against the inflammation Tannins, phytosterols and flavonoids are anti-inflammatory. They also reduce the pain, tenderness, redness, swelling like features and thus help control the symptom of infection. ${ }^{14}$

Wound Healing Activity: By glycosides and phytosterols, it promotes the healing, and reduces wound size and approximate wound margins. Tannins and phytosterols promote the healing process by wound contraction with increased capillary formation. Tannins have been reported to possess ability to increase the collagen content, which is one of the factors for promotion of wound healing.

Antimicrobial Activity: Antimicrobial test of Panchvalkal ointment had done on four bacteria S. aureus, E. coli, S. pyogens and Psedomonas and one fungi Candida albicans also, shows zone of clearance against each micro-organism and very much effective against $\mathrm{S}$. aureus with MIC of 7.81 $\mu \mathrm{g} / \mathrm{mL}$. Hence, it is proved that Panchvalkal ointment worked against this organism and controlled the sign and symptom of infected wound. The flavonoids rich fraction of the bark of Pareesha, Vata, Ashwatha and Plaksha was proven to possess good in-vitro antioxidant property, hence protect the tissue from the oxidative damage. ${ }^{15}$

\section{Conclusion}

The wound status continuum between the two groups after treatment was compared. In Group A, 30.0\% wound achieved tissue health, $36.7 \%$ healed, 26.7 regenerated and 
6.7\% improved. In Group B, only $13.3 \%$ wound achieved tissue health, $30.0 \%$ healed, $43.3 \%$ regenerated and $13.3 \%$ improved.

The clinical analysis of objective parameters showed that both the medicines were effective to control wound infection, but it was observed that control in sign and symptom of wound infection was rapid in Group A and led to wound healing with less time duration in comparison to Group B.

From the statistical data, both the groups were significantly effective in management of Dushta vrana (infected wound) and results were much improved in Group A with comparison Group B. So, we can conclude that Panchvalkal ointment was more significant than Framycetin Sulfate Cream in the management of Dushta Vrana (infected wound).

However, wound microbiology study is required to prove the reduction of microorganism colonization and histopathology study to prove the mechanism of healing of wound. Also, multi centric trial can be carried out with larger sample size to establish this treatment.

\section{Conflict of Interest: None}

\section{References}

1. Love and Baily, Short Practice of Surgery. $25^{\text {th }}$ edition. Norman S Williums, Edward Arnold (Publisher) Ltd. 2008; 24.

2. Bhat M Sriram. Manual of Surgery. $4^{\text {th }}$ edition, Jaypee Brothers Medical Publishers (P) Itd. 2013; 5-7 \& 14-18.

3. Bowler PG, Duerden I, Armstrong DG. Wound microbiology and associated approaches to wound management. clinical microbiology reviews 2001; 14(2): 244-269. Avaliable from: https://cmr.asm.org/ content/14/2/244.short [Google Scholar].

4. Wound infection \& pain management. wound infection and pain management made easy. wounds international 2010; 1(3): Available from: http://www. woundsinternational.com.

5. Sushruta, Sushruta Samhita, Part-I, Ayurveda Tatwa Sandeepika Hindi Commentary, Edited by Kaviraj Ambika Dutta Shastri, Sutrastana-Vrana prashna aadhyaya 21/40, Chaukhamba Sanskrit Sansthan, Varanasi, Edition 13, 2002; 94.

6. Sushruta, Sushruta Samhita, Part-I, Ayurveda Tatwa Sandeepika Hindi Commentary, Edited by Kaviraj Ambika Dutta Shastri, Chikitsasthana - Dvivraneeya Chikitsa 1/8, Chaukhamba Sanskrit Sansthan, Varanasi, Edition-13, 2002; 4,8,19.

7. Sakhitha KS, Dattatray D, Santhosh B, Suresh P. Formulation, anti-bacterial activity and wound healing property of panchavalkaladi ointment. International ayurvedic medical journal 2013; 1(4): 1-5. Available from: http://www.iamj.in/posts/images/upload/ iamj4.1.pdf.

8. Bhat KS, Vishwesh BN, Sahu M, Shukla VK. A clinical study on the efficacy of panchavalkala cream in vrana shodhana w.s.r to its action on microbial load and wound infection. Ayu 2014; 35(2): 135-140. [ResearchGate/ PubMed/ Google Scholar].

9. Salem MZM, Salem AZM, Camacho LM, Ali HM. Antimicrobial activities and phytochemical composition of extracts of ficus species: an over view. African Journal of Microbiology Research 2013; 7(33): 4207-4219. Avaliable from: https://academicjournals.org/article/ article1380273000_Salem\%20et\%20al.pdf [Google Scholar].

10. Bates-Jensen BM, McNees P. Toward an intelligent wound assessment system. Ostomy Wound Manage 1995; 41(suppl 7a): 80s-85s. [PubMed/ Google Scholar].

11. Shri Bhavamishra, Bhavprakasha, Poorva Khanda. Mishraprakaranam, 6/202. In: Mishra SB, Vaishya SR, editors. $8^{\text {th }}$ ed. I. Varanasi: Chaukhambha Sanskrit Bhawan; 2012; 189.

12. Asolkar LV, Kakar KK, Chakraborty OJ. New Delhi: Publications and Information Directorate, Council of Scientific and Industrial Research; 1965. A Glossary of Indian Medicinal Plants with Active Principal. Part-I; 81.

13. Vagbhata, Ashtanga Hridaya, Sutrasthana . Rasabhedeeya Adhyaya, 10/21. In: Vaidya BH, editor. 9th ed. Varanasi: Chaukhamba Orientalia Publication; 2002; 176.

14. Patil VV, Pimpikar VR. Pharmacognostical studies and evaluation of anti-inflammatory activity of Ficus bengalensis linn. J Young Pharm 2009; 1(1): 110-111. Avaliable from: http://www.jyoungpharm.in/article. asp?issn=0975-1483; year=2009; volume=1;issue=1; spage $=49$; epage $=53$; aulast $=$ Patil $[$ PubMed $/$ Goolge Scholar].

15. Preeti R, Devanathan VV, Loganathan M. Antimicrobial and antioxidant efficacy of some medicinal plants against food borne pathogens. Adv Biol Res 2010; 4: 122-125. [ResearchGate]. 